\title{
PENGARUH PENDEKATAN STEM BERBASIS ETNOMATEMATIKA TERHADAP PEMAHAMAN KONSEP DAN MINAT BELAJAR SISWA KELAS V MIN PANGKAJENE KEPULAUAN
}

\author{
Winahyu ${ }^{1}$, Ma'rufi $^{2}$, Muhammad Ilyas ${ }^{3}$ \\ MIN Pangkajene Kepulauan ${ }^{1}$, Universitas Cokroaminoto Palopo ${ }^{2,3}$ \\ wincekell@gmail.com ${ }^{1}$, marufi.ilyas@gmail.com ${ }^{2}$, muhammadilyas@uncp.ac.id $^{3}$
}

Abstrak

Penelitian ini bertujuan untuk mengetahui pengaruh pendekatan STEM berbasis etnomatematika terhadap pemahaman konsep dan minat belajar siswa kelas V MIN Pangkajene Kepulauan. Penelitian ini merupakan penelitian kuasi eksperimen dengan satuan eksperimen yang dilakukan pada satu kelas V di MIN Pangkajene Kepulauan. Penentuan satuan eksperimen dengan menggunakan teknik simple random sampling. Instrumen pada penelitian ini adalah tes pemahaman konsep, angket minat belajar, dan lembar keterlaksanaan pembelajaran. Teknik analisis data yang digunakan adalah analisis deskriptif, analisis inferensial dan kriteria pengaruh. Hasil penelitian ini adalah: (1) Kemampuan pemahaman konsep matematika siswa kelas V MIN Pangkajene Kepulauan sebelum pembelajaran dengan pendekatan STEM berbasis etnomatematika berada pada kategori rendah, (2) Kemampuan pemahaman konsep matematika siswa kelas V MIN Pangkajene Kepulauan setelah pembelajaran dengan pendekatan STEM berbasis etnomatematika berada pada kategori sangat baik, (3) Minat belajar matematika siswa kelas V MIN Pangkajene Kepulauan sebelum pembelajaran dengan pendekatan STEM berbasis etnomatematika berada pada kategori sedang, (4) Minat belajar matematika siswa kelas V MIN Pangkajene Kepulauan setelah pembelajaran dengan pendekatan STEM berbasis etnomatematika berada pada kategori sangat tinggi, (5) Terdapat peningkatan kemampuan pemahaman konsep matematika siswa kelas V MIN Pangkajene Kepulauan setelah pembelajaran dengan pendekatan STEM berbasis etnomatematika, (6) Terdapat perbedaan minat belajar matematika siswa kelas $\mathrm{V}$ MIN Pangkajene Kepulauan sebelum dan setelah pembelajaran dengan pendekatan STEM berbasis etnomatematika.

Kata kunci: STEM, etnomatematika, pemahaman konsep, minat belajar

\section{A. Pendahuluan}

Pendidikan sangat berperan dalam kehidupan kita karena pendidikan merupakan wahana dalam proses peningkatan kualitas sumber daya manusia secara menyeluruh. Menyadari pentingnya proses peningkatan kualitas sumber daya manusia, maka pemerintah telah turun tangan mewujudkan amanat tersebut. Salah satu usahanya adalah dengan pembangunan pendidikan yang berkualitas. Usaha 
tersebut antara lain pengembangan dan perbaikan kurikulum, sarana pendidikan, pengembangan dan pengadaan materi ajar, sistem evaluasi, serta pelatihan bagi guru dan tenaga kependidikan serta pengembangan terkait pembelajaran.

Terkait dengan pembelajaran matematika di tingkat SD sampai SMA, salah satu kecakapan yang seharusnya dimiliki siswa adalah kemampuan pemahaman konsep matematika. Ma'rufi, Pasandaran, dan Yogi (2018) menyatakan pemahaman konsep adalah suatu tingkat kemampuan yang ketika dimiliki siswa, mereka mampu memahami dan menjelaskan maksud/arti dari suatu konsep. Ketika siswa benar-benar memahami suatu konsep matematika, bukan sekadar menghafal, maka hal tersebut akan membantu siswa dalam menyelesaikan masalah matemtika yang membutuhkan kemampuan berpikir tingkat tinggi.

Indikator pemahaman konsep berdasarkan Depdiknas (Zuliana, 2017) antara lain menyatakan ulang sebuah konsep, mengklasifikasi sebuah objek menurut sifatsifat tertentu sesuai dengan konsepnya, memberikan contoh dan non contoh dari sebuah konsep, menyajikan konsep dalam berbagai bentuk representasi matematis, mengembangkan syarat perlu dari suatu konsep. Selain itu indikator lainnya adalah menggunakan, memanfaatkan dan memilih prosedur atau operasi tertentu, serta mengaplikasikan konsep ke pemecahan masalah.

Kenyataanya pembelajaran matematika di MIN Pangkajene Kepulauan belum menjadikan siswa paham dengan konsep dari materi matematika. Pembelajaran didominasi guru dengan pemberian rumus-rumus dan konsep-konsep secara verbal. Menghadapi kondisi tersebut, guru dituntut untuk mampu melakukan pembelajaran yang kreatif dan inovatif yang menjadikan siswa terlibat dengan perasaan senang dalam pembelajaran. Hal ini sesuai dengan tututan yang seharusnya diterapkan guru di era 4.0 ini.

Selain masalah terkait pemahaman terhadap konsep matematika, siswa juga memiliki minat yang terbilang kurang terhadap matematika. Saat pembelajaran, siswa cenderung pasif, jika diberikan kesempatan untuk memberikan pertanyaan sangat jarang ditemukan siswa yang bertanya, namun ketika diberikan permasalahan matematika, hanya sebagian kecil siswa di kelas tersebut mampu menyelesaikannya. Peneliti selaku guru menyadari bahwa penting untuk 
menerapkan pembelajaran yang menjadikan siswa berminat belajar matematika dan tentunya menjadikan siswa memahami konsep dari materi yang diajarkan.

Salah satu pendekatan pembelajaran yang dapat diterapkan untuk menjawab masalah tersebut adalah pendekatan STEM (Science, Technology, Engineering and Mathematics) berbasis etnomatematika. STEM sendiri menjadi isu penting pendidikan saat ini. Pembelajaran dengan menggunakan pendekatan STEM mengintegrasikan pembelajaran sains, teknologi, teknik, dan matematika dalam membantu kesuksesan keterampilan abad 21. Hartono dan Hiltrimartin (2017) menjelaskan STEM merupakan suatu pendekatan pembelajaran yang terbentuk sebagai perpaduan beberapa disiplin ilmu yaitu sains, teknologi, teknik, dan matematika. Kolaborasi pembelajaran STEM membantu siswa dalam mengumpulkan dan menganalisis serta memecahkan suatu permasalahan yang terjadi serta mampu untuk memahami keterkaitan permasalahan yang satu dengan yang lainnya. STEM mengakomodir siswa untuk terlibat secara alami alam pembelajaran sehingga memberikan pengalaman belajar yang bermakna bagi siswa termasuk dalam hal kemampuan pemahaman konsep. Hasil penelitian Ramadhani (2018) diketahui bahwa kemampuan pemahaman konsep dan minat siswa meningkat setelah menggunakan pendekatan STEM. Sedangkan menurut Sari (2017) STEM sesuai dengan tujuan kurikulum 2013 yang menekankan pada proses keterampilan berpikir kritis, kreatif, dan inovatif pada aspek kemampuan esensial yang dalam membangun negara pada masa mendatang.

Di sisi lain menurut D'Ambrosio (Fajriyah, 2018) Etnomatematika dapat menjembatani antara budaya dan pendidikan, khususnya pendidikan matematika. Dalam bidang pendidikan matematika, etnomatematika masih merupakan kajian yang baru dan berpotensi sangat baik untuk dikembangkan menjadi inovasi pembelajaran kontekstual sekaligus mengenalkan budaya Indonesia kepada siswa sehingga bidang etnomatematika dapat digunakan sebagai pusat proses pembelajaran dan metode pengajaran, walaupun masih relatif baru dalam dunia pendidikan. Berdasarkan hasil penelitian yang dilakukan Sarwoedi (2018) diperoleh hasil bahwa pembelajaran matematika berbasis etnomatematika terbukti efektif dalam meningkatkan kemampuan pemahaman matematika siswa. Hal ini terbukti bahwa dari hasil penelitian dan beberapa indiktor kemampuan pemahaman 
siswa menyatakan bahwa ada pengaruh etnomatematika terhadap kemampuan pemahaman matematika siswa, yaitu dalam hal mengidentifikasi, menerjemah, menafsirkan makna simbol, memahamai dan menerapkan ide matametis, serta membuat suatu eksplorasi (perkiraan).

\section{B. Metode Penelitian}

Jenis penelitian yang digunakan dalam penelitian ini adalah kuasi eksperimen dengan pendekatan kuantitatif. Desain penelitian yang digunakan untuk keperluan penyelidikan yaitu One Group Pretest-Posttest Design menggunakan satu kelompok perlakuan dengan pemberian pretest dan posttest.

Satuan eksperimen dalam penelitian ini dilakukan pada satu kelas V di MIN Pangkajene Kepulauan. Dipilih satu kelas sebagai kelas eksperimen, yaitu kelas yang diajar dengan pendekatan STEM berbasis etnomatematika. Penentuan kelas perlakuan dalam penelitian ini menggunakan teknik simple random sampling. Instrumen yang digunakan adalah tes pemahaman konsep, angket minat belajar, dan lembar keterlaksanaan pembelajaran.

Pengumpulan data untuk hasil pemahaman konsep matematika dilakukan dengan dua tahap. Tahap pertama yaitu pemberian tes awal (pretest) dan tahap kedua yaitu pemberian tes akhir (posttest). Data minat belajar siswa diperoleh melalui angket minat belajar yang diberikan sebelum dan setelah pembelajaran dengan STEM berbasis etnomatematika. Data keterlaksanaan pembelajaran diperoleh dengan melakukan pengamatan terhadap aktivitas pembelajaran yang mengacu pada langkah-langkah metode pembelajaran yang disesuaikan dengan RPP selama kegiatan pembelajaran berlangsung.

Teknik analisis data yang digunakan yaitu analisis data deskriptif dan analisis data inferensial. Analisis deskriptif digunakan untuk menganalisis data tes pemahaman konsep matematika, data minat belajar, dan data kertelaksanaan pembelajaran. Teknik analisis data dengan statistik inferensial digunakan untuk keperluan pengujian hipotesis penelitian. Untuk pengujian hipotesis digunakan statistik parametrik dengan uji-t. Dengan taraf signifikansi untuk menguji hipotesis dengan $a=0,05$. 
Uji hipotesis 1 dilakukan untuk melihat adanya peningkatan kemampuan pemahaman konsep sebelum dan setelah diberikan perlakuan berupa pembelajaran dengan pendekatan STEM berbasis etnomatematika. Untuk menguji hipotesis ini digunakan jenis uji-t yaitu one sample T-test untuk menguji apakah terdapat peningkatan sampel. Hipotesis ini dinyatakan sebagai berikut:

$$
H_{0}: \mu_{B} \leq 0,29 \text { melawan } H_{1}: \mu_{B}>0,29
$$

Di mana, $\mu_{B}=$ parameter selisih rata-rata hasil gain ternormalisasi tes pemahaman konsep matematika siswa kelas V di MIN Pangkajene Kepulauan sebelum dan setelah diterapkan pembelajaran dengan pendekatan STEM berbasis etnomatematika.

Uji hipotesis 2 dilakukan untuk melihat adanya perbedaan minat belajar matematika sebelum dan setelah diberikan perlakuan berupa pembelajaran dengan pendekatan STEM berbasis etnomatematika. Untuk menguji hipotesis ini digunakan jenis uji-t yaitu paired sample T-test. Hipotesis ini dinyatakan sebagai berikut:

$$
H_{0}: \mu_{1}=\mu_{2} \quad \text { melawan } \quad H_{1}: \mu_{1} \neq \mu_{2}
$$

Dimana, $\mu_{1}=$ parameter hasil tes minat belajar sebelum diajar dengan pendekata STEM berbasis etnomatematika, sedangkan $\mu_{2}=$ parameter hasil tes minat belajar setelah diajar dengan pendekatan STEM berbasis etnomatematika.

Penerapan pembelajaran dengan pendekatan STEM berbasis etnomatematika terhadap pemahaman konsep dan minat belajar siswa kelas V MIN Pangkajene Kepulauan dikatakan berpengaruh ketika memenuhi kriteria sebagai berikut:

\section{Secara deskriptif}

Secara deskriptif dikatakan berpengaruh terhadap pemahaman konsep matematika dan minat belajar matematika siswa apabila memenuhi kriteria sebagai berikut:

a. Rata-rata gain ternomalisasi pemahaman konsep matematika minimal berada pada kategori sedang $(0,3 \leq \mathrm{g}<0,7)$.

b. Rata-rata minat belajar matematika siswa minimal berada pada kategori tinggi $(63-81)$. 
c. Rata-rata hasil observasi keterlaksanaan pembelajaran dengan pendekatan STEMminimal berada pada kategori baik (80-89).

2. Secara inferensial

Secara inferensial dikatakan berpengaruh terhadap pemahaman konsep dan minat belajar matematika siswa apabila peningkatan pemahaman konsep matematika dengan pendekatan STEM berbasis etnomatematika lebih dari skor rata-rata gain ternomalisasi dan adanya perbedaan minat belajar matematika sebelum dan setelah diberikan perlakuan berupa pembelajaran dengan pendekatan STEM berbasis etnomatematika.

\section{Hasil Penelitian dan Pembahasan}

1. Hasil Penelitian

Untuk pemahaman konsep siswa, nilai rata-rata pretest siswa adalah 48,39 dengan standar deviasi 14,91 dari nilai ideal 100 berada pada kriteria pemahaman konsep matematika rendah. Sedangkan nilai rata-rata posttest siswa setelah pembelajaran dengan pendekatan STEM berbasis etnomatematika adalah 85,36 dengan standar deviasi 7,68 dari nilai ideal 100 berada pada kriteria pemahaman konsep sangat baik.

Berdasarkan data pretest dan posttest berkaitan dengan pemahaman konsep matematika siswa maka selanjutnya dilakukan analisis nilai gain terhadap peningkatan pemahaman konsep matematika siswa. Hasil analisis tentang peningkatan pemahaman konsep matematika siswa sebelum dan setelah pembelajaran dengan pendekatan STEM berbasis etnomatematika dapat dilihat pada tabel berikut.

Tabel 1. Statistik deskriptif peningkatan nilai pretest ke posttest pemahaman konsep matematika siswa

\begin{tabular}{cc}
\hline Statistik & Nilai Statistik Pretest \\
\hline Ukuran Sampel & 20 \\
Nilai Ideal & 1,00 \\
Nilai Tertinggi & 1,00 \\
Nilai Terendah & 0,59 \\
Rentang Nilai & 0,41 \\
Nilai Rata-rata & 0,734 \\
Variansi & 0,009 \\
Standar Deviasi & 0,093 \\
\hline
\end{tabular}

Sumber: Hasil analisis data primer 2020 
Apabila peningkatan pemahaman konsep matematika siswa dikelompokkan ke dalam tiga klasifikasi gain, maka diperoleh distribusi frekuensi dan persentase pada tabel berikut.

Tabel 2. Klasifikasi gain ternormalisasi pemahaman konsep matematika siswa

\begin{tabular}{cccc}
\hline Koefisien Normalisasi Gain & Klasifikasi & Frekuensi & Persentase \\
\hline $\mathrm{g}<0,3$ & Rendah & 0 & $0 \%$ \\
$0,3 \leq \mathrm{g}<0,7$ & Sedang & 8 & $40 \%$ \\
$\mathrm{~g} \geq 0,7$ & Tinggi & 12 & $60 \%$ \\
\hline Jumlah & & 20 & $100 \%$ \\
\hline
\end{tabular}

Sumber: Hasil analisis data primer 2020

Berdasarkan tabel 1 dan 2 di atas, nilai rata-rata peningkatan pemahaman konsep matematika siswa dengan pembelajaran STEM berbasis etnomatematika sebesar 0,734 dengan standar deviasi 0,093 dari skor ideal 1. Rata-rata peningkatan pemahaman konsep tersebut berada pada klasifikasi tinggi.

Untuk pengujian hipotesis, pengujian rata-rata peningkatan pemahaman konsep matematika siswa dilakukan dengan uji-t yaitu one sample T-test. Keluaran dari hasil pengujian hipotesis disajikan pada tabel berikut.

Tabel 3. Uji hipotesis peningkatan pemahaman konsep matematika siswa

\begin{tabular}{ccccccccc}
\hline & & & & & & \multicolumn{3}{c}{$\begin{array}{c}95 \% \text { Confidence } \\
\text { Interval of } \\
\text { Difference }\end{array}$} \\
\cline { 2 - 9 } & $t$ & $d f$ & $\begin{array}{c}\text { Sig. } \\
\text { tailed) }\end{array}$ & $\begin{array}{c}\text { Mean } \\
\text { Difference }\end{array}$ & $\begin{array}{c}\text { Std. Error } \\
\text { Difference }\end{array}$ & Lower & Upper \\
\hline Gain & 21,368 & 19 &, 000 &, 44337 &, 3999 &, 4868 & 21,368 \\
PKM & 19 & &
\end{tabular}

Sumber: Hasil analisis data primer 2020

Berdasarkan tabel One-Sample Statistic di atas terlihat bahwa Sig. (2-tailed) pada peningkatan pemahaman konsep matematika siswa adalah $0,000<0,05$. Hal ini berarti bahwa $\mathrm{H}_{0}$ ditolak dan $\mathrm{H}_{1}$ diterima yaitu gain ternormalisasi pemahaman konsep matematika siswa yang diajar dengan pendekatan STEM berbasis etnomatematika secara signifikan lebih besar dari 0,29 (kategori sedang). Sehingga dapat dikatakan terjadi peningkatan pemahaman konsep matematika siswa dan hal ini juga menunjukkan bahwa secara inferensial memenuhi kriteria pengaruh.

Terkait dengan minat belajar matematika siswa, rata-rata pretest minat belajar matematika siswa sebelum diajar dengan pendekatan STEM berbasis etnomatematika adalah 60,44 dengan standar deviasi 12,84 dari skor ideal 100 berada pada kriteria sedang. Sedangkan rata-rata posttest minat belajar matematika 
siswa setelah diajar dengan pendekatan STEM berbasis etnomatematika adalah 84,81 dengan standar deviasi 7,67 dari skor ideal 100 berada pada kriteria sangat tinggi.

Pengujian hipotesis untuk melihat adanya perbedaan minat belajar matematika sebelum dan setelah diberikan perlakuan berupa pembelajaran dengan pendekatan STEM berbasis etnomatematika digunakan jenis uji-t yaitu paired sample T-test. Keluaran dari hasil pengujian hipotesis disajikan pada tabel berikut. Tabel 4. Uji hipotesis perbedaan pretest dan posttest minat belajar matematika

\begin{tabular}{|c|c|c|c|c|c|c|c|c|}
\hline & \multicolumn{5}{|c|}{ Paired Differences } & \multirow{3}{*}{$t$} & \multirow{3}{*}{$d f$} & \multirow{3}{*}{$\begin{array}{l}\text { Sig. }(2- \\
\text { tailed })\end{array}$} \\
\hline & \multirow[t]{2}{*}{ Mean } & \multirow[t]{2}{*}{$\begin{array}{c}\text { Std. } \\
\text { Deviation }\end{array}$} & \multirow{2}{*}{$\begin{array}{l}\text { Std. } \\
\text { Error } \\
\text { Mean }\end{array}$} & \multicolumn{2}{|c|}{$\begin{array}{l}95 \% \text { Confidence } \\
\text { Interval of } \\
\text { Difference }\end{array}$} & & & \\
\hline & & & & Lower & Upper & & & \\
\hline $\begin{array}{l}\text { Pretest- } \\
\text { Posttest }\end{array}$ & ,95408 & ,48911 & ,10937 &, 72517 & 1,18299 & 8,724 & 19 &, 000 \\
\hline
\end{tabular}

Sumber: Hasil analisis data primer 2020

Berdasarkan tabel Paired Samples Test di atas terlihat bahwa Sig. (2-tailed) sebesar $0,000<0,05$. Hal ini berarti bahwa $\mathrm{H}_{0}$ ditolak dan $\mathrm{H}_{1}$ diterima yaitu minat belajar matematika sebelum pembelajaran dengan pendekatan STEM berbasis etnomatematika tidak sama dengan minat belajar matematika siswa setelah pembelajaran dengan pendekatan STEM berbasis etnomatematika. Sehingga dapat dikatakan terdapat perbedaan minat belajar sebelum dan setelah pembelajaran dengan pendekatan STEM berbasis etnomatematika.

Aktivitas pembelajaran yang diobservasi adalah aktivitas pembelajaran dengan pendekatan STEM berbasis etnomatematika. Observasi terhadap keterlaksanaan pembelajaran tersebut mengacu pada Rencana Pelaksanaan Pembelajaran (RPP). Observasi dari seorang observer (pengamat) terhadap keterlaksanaan pembelajaran selama 6 kali pertemuan dengan kategori penilaian sebagai berikut: "Ya" berarti "terlaksana" dan "Tidak" berarti "tidak terlaksana". Hasil observasi terhadap keterlaksanaan pendekatan STEM berbasis etnomatematika dalam proses pembelajaran dapat dilihat pada tabel berikut: 
Tabel 4. Data hasil observasi keterlakasanaan pendekatan STEM berbasis etnomatematika

\begin{tabular}{ccc}
\hline Pertemuan & Persentasi rata-rata $(\%)$ & Kategori \\
\hline I & 87,50 & Baik \\
II & 82,35 & Baik \\
III & 81,25 & Baik \\
IV & 86,96 & Baik \\
V & 82,35 & Baik \\
VI & 81,25 & Baik \\
\hline Skor rata-rata & 83,61 & Baik
\end{tabular}

Sumber: Hasil analisis data primer 2020

Berdasarkan tabel di atas tampak bahwa rata-rata keterlaksanaan pembelajaran dengan pendekatan STEM berbasis etnomatematika berada pada kategori baik. Sehingga keterlaksanaan pembelajaran pada kelas yang diajar dengan dengan pendekatan STEM berbasis etnomatematika secara deskriptif memenuhi kriteria pengaruh.

Berikut ini tabel pencapaian kriteria pengaruh pendekatan STEM berbasis etnomatematika secara deskriptif.

Tabel 5. Pencapaian kriteria pengaruh pendekatan STEM berbasis etnomatematika secara deskriptif

\begin{tabular}{lcc}
\hline \multicolumn{1}{c}{ Kriteria pengaruh } & Pencapaian & Kategori \\
\hline $\begin{array}{l}\text { Rata-rata gain ternomalisasi pemahaman } \\
\text { konsep matematika }\end{array}$ & 0,734 & Tinggi \\
\hline $\begin{array}{l}\text { Rata-rata hasil observasi keterlaksanaan } \\
\text { pembelajaran dengan pendekatan STEM }\end{array}$ & 83,61 & Baik \\
\hline
\end{tabular}

Sumber: Hasil analisis data primer 2020

Berdasarkan tabel pencapaian kriteria pengaruh pendekatan STEM berbasis etnomatematika secara deskriptif di atas, terlihat bahwa capaian rata-rata gain ternormalisasi pemahaman konsep matematika adalah 0,734 dengan kategori tinggi dan capaian rata-rata observasi keterlaksanaan pembelajaran dengan pendekatan STEM berbasis etnomatematika adalah 83,61 dengan kategori baik. Artinya secara deskriptif pendekatan STEM berbasis etnomatematika berpengaruh terhadap pemahaman konsep matematika siswa kelas V MIN Pangkajene Kepulauan.

Berikut ini tabel pencapaian kriteria pengaruh pendekatan STEM secara inferensial. 
Tabel 6. Pencapaian kriteria pengaruh pendekatan STEM secara inferensial

\begin{tabular}{ll}
\hline \multicolumn{1}{c}{ Kriteria pengaruh } & Probabilitas \\
\hline Peningkatan pemahaman konsep matematika dengan pendekatan & $0,000<0,05$ \\
STEM & \\
\hline
\end{tabular}

Sumber: Hasil analisis data primer 2020

Berdasarkan tabel di atas, terlihat bahwa probabilitas untuk peningkatan pemahaman konsep matematika dengan pendekatan STEM berbasis etnomatematika adalah $0,000<0,05$ artinya $H_{1}: \mu_{B}>0,29$ diterima. Hal tersebut menandakan bahwa peningkatan pemahaman konsep matematika dengan pendekatan STEM berbasis etnomatematika lebih dari skor rata-rata gain ternomalisasi. Karena kriteria pengaruh terpenuhi maka secara inferensial dapat disimpulkan bahwa pendekatan STEM berbasis etnomatematika berpengaruh terhadap pemahaman konsep siswa kelas V MIN Pangkajene Kepulauan.

2. Pembahasan

Pemahaman konsep matematika siswa kelas V MIN Pangkajene Kepulauan tentang materi bangun ruang awalnya berada pada kategori rendah. Selama ini siswa belum terlibat secara alami dalam proses belajar sehingga berdampak pada pengalaman belajar yang mereka peroleh. Rata-rata pemahaman konsep matematika siswa setelah diajar dengan pendekatan STEM berbasis etnomatematika (posttest) meningkat menjadi kategori sangat baik. Peningkatan pemahaman konsep matematika siswa dengan pembelajaran STEM berbasis etnomatematika berada pada klasifikasi tinggi. Hal ini juga sejalan dengan penelitian dari Utami dkk (2017) yang menyatakan bahwa adanya peningkatan pemahaman konsep siswa setelah diterapkan pembelajaran STEM-A (Sciences, Technology, Engineering, Mathematics, and Animation).

Dengan keterlibatan siswa dalam eksplorasi STEM berbasis etnomatematika secara alami mengembangkan keingintahuan, mengembangkan minat untuk belajar berbagai hal, mengembangkan daya berpikir kritis, dan pemecahan masalah termasuk hal-hal yang berkaitan dengan budaya yang dikaitkan dengan matematika. Hal tersebut sejalan dengan penelitian Suwarma (2015) yang hasil penelitiannya menunjukkan bahwa pembelajaran berbasis STEM ini mampu meningkatkan motivasi dan memberikan pengalaman dalam proses engineering (rekayasa). Selain itu, pembelajaran ini mampu meningkatkan prestasi siswa dalam ujian akhir sekolah. 
Perbedaan jawaban di setiap indikator saat pretest dan posttest menunjukkan bahwa setelah belajar dengan pendekatan STEM berbasis etnomatematika siswa dapat memberikan jawaban yang lebih baik. Hal ini terlihat dari jawaban keseluruhan siswa pada berdasarkan indikator pemahaman konsep matematika materi bangun ruang balok yaitu:

a. Menyatakan ulang sebuah konsep

Sebagian besar siswa sudah mampu menyatakan ulang konsep bangun ruang balok. Butir soal pada indikator ini yaitu "tuliskan sifat-sifat bangun ruang yang tampak pada gambar!". Pada jawaban siswa tampak bahwa siswa sudah mampu menyebutkan banyaknya rusuk balok adalah 12 , sisi sebanyak 6 , dan titik sudut balok sebanyak 8. Selain itu siswa juga sudah mampu menuliskan sifat dari tabung, yaitu banyak rusuknya 2 , sisinya sebanyak 3 , dan tidak memiliki titik sudut.

b. Mengklasifikasi sebuah objek menurut sifat-sifat tertentu sesuai dengan konsepnya

Pada indikator ini sebagian besar siswa sudah mampu mengklasifikasi sebuah objek menurut sifat-sifat tertentu sesuai dengan konsepnya. Butir soal untuk indikator ini siswa diminta untuk menuliskan bangun ruang yang terlihat pada gambar. Pada jawaban siswa terlihat bahwa siswa sudah mampu mengklasifikasi bahwa bangun ruang dalam gambar merupakan bangun ruang balok ataupun tabung.

c. Memberikan contoh dan non contoh dari sebuah konsep

Pada indikator ini sebagian besar siswa sudah mampu memberikan contoh dan non contoh dari sebuah konsep. Pada indikator ini siswa diminta menuliskan 3 benda yang bentuknya sama dengan bangun ruang yang ada pada gambar. Dari jawaban siswa terlihat bahwa siswa sudah mampu meberikan contoh dari bangun ruang balok dan tabung. Paling banyak siswa menuliskan penghapus sebagai contoh benda balok dan spidol sebagai benda tabung.

d. Menyajikan konsep dalam berbagai bentuk representasi matematis

Pada indikator ini sebagian siswa sudah mampu menyajikan konsep dalam berbagai bentuk representasi matematis. Pada indikator ini siswa diminta menggambar sebuah bangun ruang yang sejenis dengan bangun ruang pada gambar. Untuk balok ukuran panjangnya dua kali dari lebarnya, dan ukuran lebarnya dua 
kali dari tingginya. Sedangkan untuk tabung siswa diminta menggambar tabung dengan ukuran tinggi tabung sama dengan diameternya. Dari jawaban siswa terlihat bahwa sebagian siswa sudah bisa menggambar balok dengan syarat ukuran panjang, lebar, dan tinggi dengan benar, serta menggambar tabung dengan syarat ukuran diameter dan tinggi tabung yang benar pula.

e. Mengembangkan syarat perlu dari suatu konsep

Pada indikator ini sebagian besar siswa sudah mampu mengembangkan syarat perlu dari suatu konsep. Hal ini dilihat dari kemampuan siswa dalam menganalisis gambar apakah gambar tersebut merupakan bangun ruang yang sama dengan soal untuk indikator pertama dengan menjelaskan alasannya. Siswa diberikan gambar sebuah bangun ruang yang berbentuk kubus, lalu siswa menentukan apakah gambar tersebut masih termasuk bangun ruang balok. Sebagian besar siswa menjawab bahwa bangun ruang kubus tersebut termasuk bangun ruang balok karena dilihat dari sifat/jumlah dari rusuk, sisi, dan titik sudut balok. Selain itu siswa diberikan gambar bambu yang salah satu ujungnya runcing. Siswa mengkategorikan bahwa gambar tersebut bukan merupakan tabung karena bagian atasnya (tutup) tidak berbentuk lingkaran.

f. Menggunakan, memanfaatkan dan memilih prosedur atau operasi tertentu

Pada indikator ini sebagian besar siswa sudah mampu menggunakan, memanfaatkan dan memilih prosedur atau operasi tertentu. Siswa diminta untuk menuliskan rumus menghitung volume bangun ruang pada gambar. Siswa sudah mampu menjawab bahwa rumus menghitung volume balok yaitu dengan mengalikan panjang, lebar, dan tinggi balok tersebut, serta rumus menghitung volume tabung adalah dengan mengalikan luas alas tabung yang berbentuk lingkaran dengan tinggi tabung tersebut.

g. Mengaplikasikan konsep ke pemecahan masalah

Pada indikator ini sebagian besar siswa sudah mampu mengaplikasikan konsep ke pemecahan masalah. Siswa diminta menyelesaikan masalah sehari-hari tentang balok dan tabung yaitu menghitung volume balok dan tabung yang diketahui ukurannya. Siswa menjawab soal dengan menggunakan rumus volume balok yaitu mengalikan panjang, lebar, dan tinggi balok serta menggunakan rumus 
volume tabung yaitu dengan mengalikan luas alas yang berbentuk lingkaran dengan tinggi tabung.

Minat belajar matematika siswa kelas V MIN Pangkajene Kepulauan berdasarkan data pretest berada pada kategori sedang. Hal ini disebabkan ketertarikan siswa terhadap matematika masih kurang sehingga diperlukan pembelajaran yang mengakomodir keterlibatan siswa yang pada akhirnya di dalam diri siswa ada rasa senang, perhatian, dan ketertarikan pada matematika. Setelah diajar dengan pendekatan STEM berbasis etnomatematika, minat belajar mereka berada pada kategori sangat tinggi. Hal ini sesuai dengan penelitian Ramadhani (2018) yang menyatakan bahwa minat siswa meningkat setelah menggunakan pendekatan STEM.

Berikut ini merupakan penjelasan dari setiap indikator terkait minat belajar matematika siswa.

a. Perasaan senang

Perasaan senang siswa terhadap matematika tumbuh dan berkembang dengan penerapan pendekatan STEM berbasis etnomatematika ini. Berdasarkan posttest minat belajar matematika, siswa menjadi lebih senang belajar matematika di kelas, mencari sumber belajar matematika di internet dan tidak senang jam matematika kosong.

b. Ketertarikan siswa

Ketertarikan siswa terhadap pelajaran matematika menjadi lebih besar dengan penerapan pendekatan STEM berbasis etnomatematika ini. Siswa lebih memahami materi yang diajarkan oleh guru, merasa penasaran jika latihan soal tidak berhasil mereka selesaikan, dan selalu bersemangat setiap kali belajar matematika.

c. Perhatian siswa

Perhatian siswa terhadap pelajaran matematika menjadi lebih besar dengan penerapan pendekatan STEM berbasis etnomatematika ini. Siswa mencatat semua materi matematika yang disampaikan guru dan selalu memberi tanda catatan yang dianggap penting. 


\section{d. Keterlibatan siswa}

Siswa lebih terlibat dalam pembelajaran matematika dengan penerapan pendekatan STEM berbasis etnomatematika ini. Mereka akan bertanya jika ada hal yang tidak dipahami dan menjadi lebih suka berdiskusi dengan temannya.

Berdasarkan hasil penelitian dan pembahasan di atas dapat disimpulkan bahwa pendekatan STEM berbasis etnomatematika berpengaruh terhadap pemahaman konsep dan minat belajar matematika siswa kelas V MIN Pangkajene Kepulauan.

\section{Kesimpulan}

Dari pelakasanaan kegiatan pembelajaran yang terlah dilakukan dia atas dapat diperoleh kesimpulan antara lain: (1) Kemampuan pemahaman konsep matematika siswa kelas V MIN Pangkajene Kepulauan sebelum pembelajaran dengan pendekatan STEM berbasis etnomatematika berada pada kategori rendah, (2) Kemampuan pemahaman konsep matematika siswa kelas V MIN Pangkajene Kepulauan setelah pembelajaran dengan pendekatan STEM berbasis etnomatematika berada pada kategori sangat baik, (3) Minat belajar matematika siswa kelas V MIN Pangkajene Kepulauan sebelum pembelajaran dengan pendekatan STEM berbasis etnomatematika berada pada kategori sedang, (4) Minat belajar matematika siswa kelas V MIN Pangkajene Kepulauan setelah pembelajaran dengan pendekatan STEM berbasis etnomatematika berada pada kategori sangat tinggi, (5) Terdapat peningkatan kemampuan pemahaman konsep matematika siswa kelas V MIN Pangkajene Kepulauan setelah pembelajaran dengan pendekatan STEM berbasis etnomatematika, dan (6) Terdapat perbedaan minat belajar matematika siswa kelas V MIN Pangkajene Kepulauan sebelum dan setelah pembelajaran dengan pendekatan STEM berbasis etnomatematika.

\section{Daftar Pustaka}

Fajriyah, Euis. 2018. Peran Etnomatematika Terkait Konsep Matematika dalam Mendukung Literasi. Jurnal Prisma 1: 114-119

Hartono, Y., \& Hiltrimartin, C. 2017. Pengembangan Buku Siswa Materi Jarak Pada Ruang Dimensi Tiga Berbasis Science, Technology, Engineering, and 
Mathematics (STEM) Problem-Based Learning di Kelas X. Jurnal Elemen, 3(1): $1-14$

Ma'rufi, Pasandaran, R. F., \& Yogi, A. (2018). Pemahaman Konsep Geometri Mahasiswa Berdasarkan Gaya Kognitif Mahasiswa. Proximal Jurnal Penelitian Matematika dan Pendidikan Matematika, 1(2), 56-67.

Ramadhani, Elfi. 2018. Kemampuan Pemahaman Konsep dan Minat Mahasiswa dengan Pendekatan STEM (Science, Technology, Engineering, Mathematics). Seminar Nasional Pendidikan Matematika, (1), 129-140.

Sari, R. H. (2017). Pengaruh Implementasi Pembelajaran Stem Terhadap Persepsi, Sikap, dan Kreativitas Siswa. Prosiding Seminar Nasional MIPA III,(1), 416420.

Sarwoedi. (2018). Efektifitas Etnomatematika dalam Meningkatkan Kemampuan Pemahaman Matematika Siswa. Jurnal Pendidikan Matematika Raflesia, 3(2), 171-176.

Suwarma, Astuti, \& Endah. (2015). "Balloon Powered Car" sebagai Media Pembelajaran IPA Berbasis STEM (Science, Technology, Engineering, And Mathematics) . Prosiding Simposium Nasional Inovasi dan Pembelajaran Sains 2015, 373-376.

Utami. (2017). Pengembangan STEM-A (Science, Technology, Engineering, Mathematic and Animation) Berbasis Kearifan Lokal dalam Pembelajaran Fisika. Jurnal Ilmiah Pendidikan Fisika Al-BiRuNi, 06(1), 67-73.

Zuliana, E. (2017). Penerapan Inquiry Based Learning Berbantuan Peraga Manipulatif dalam Meningkatkan Pemahaman Konsep Matematika Pada Materi Geometri Mahasiswa PGSD Universitas Muria Kudus. Jurnal Pendidikan, 8 (1), 35-47. 